\title{
ANALISIS FRAMING PEMBERITAAN KOTA BOGOR DI MEDIA ONLINE WWW.HEIBOGOR.COM DAN WWW.BOGORPLUS.COM
}

\section{FRAMING ANALYSIS OF BOGOR CITY'S NEWS IN ONLINE MEDIA WWW.HEIBOGOR.COM AND WWW.BOGORPLUS.COM}

\author{
D Nilamsari', IA Ratnamulyani², M Luthfie ${ }^{3}$ \\ 1)Alumni Ps. Ilmu Komunikasi, Fakultas Ilmu Sosial dan Ilmu Politik, Universitas Djuanda Bogor. 2)Dosen \\ Pembimbing I Program Studi Komunikasi, Fakultas Ilmu Sosial dan Ilmu Politik, ${ }^{3}$ Dosen Pembimbing II Program \\ Studi Komunikasi Universitas Djuanda Bogor, Jl. Tol No. 1 Kotak Pos 35 Bogor 16720 \\ a Korespondensi: I.A. Ratnamulyani, Email: ikea.ratnamulyani@yahoo.com
}

(Ditelaah: 27-07-2016; Disetujui: 26-08-2016)

\begin{abstract}
HeiBogor and BogorPlus are two local media online that both presenting news about Bogor. On their news presenting both has different principal. HeiBogor has positive journalism principal while BogorPlus has principal as media for justice. This is a qualitative research of news text about the best news in both media which is about Baranangsiang Optimalization. The analysis approach used framing theory by Gerald M. Kosicki and Zongdang Pan to know the news's background and the link between media's principal and news presenting. The result showed that HeiBogor pointed the problem of Baranangsiang Optimalization as an issue with the interest of many sides so it must be seen from many aspects to get the right solution. While BogorPlus on its news showed that the plan of building some hotel and mall buildings in Baranangsiang station was an act of law violation because it broke the Layout Regulation.
\end{abstract}

Keyword: HeiBogor.com. BogorPlus, Framing

ABSTRAK

HeiBogor dan BogorPlus adalah dua media online lokal yang sama-sama memberitakan Kota Bogor. Dalam pemberitaannya kedua media online ini memiliki prinsip yang berbeda. Media online HeiBogor memiliki prinsip jurnalisme positif sementara BogorPlus memiliki prinsip sebagai media untuk keadilan (Media for Justice). Penelitian ini merupakan sebuah penelitian kualitatif terhadap teks berita mengenai berita andalan di kedua media yaitu mengenai Optimalisasi Baranangsiang. Pendekatan analisis menggunakan teori framing Gerald M. Kosicki dan Zhongdang Pan untuk mengetahui latar belakang dan keterkaitan antara prinsip media dengan hasil pemberitaan. Hasil penelitian menunjukkan bahwa dalam pemberitaannya media online HeiBogor menonjolkan bahwa Optimalisasi Baranangsiang adalah perkara yang melibatkan kepentingan banyak pihak sehingga harus dilihat dari berbagai sisi untuk mendapatkan solusi terbaik. Sementara media online BogorPlus dalam pemberitaannya menonjolkan bahwa pembangunan hotel dan mall di Terminal Baranangsiang adalah sebuah pelanggaran hukum karena melanggar UU Tata Ruang.

Kata kunci : HeiBogor.com, BogorPlus.com, Framing

D Nilamsari, IA Ratnamulyani, M Luthfie. 2016. Analisis Framing Pemberitaan Kota Bogor di Media Online www.heibogor.com dan www.bogorplus.com. Jurnal Komunikatio 2(2): 107-114. 


\section{PENDAHULUAN}

Media massa online memiliki beberapa kelebihan dibandingkan media massa konvensional. Konsep media online yang tidak terbatas oleh dimensi ruang dan waktu menjadi daya tarik tersendiri. Perputaran berita juga menjadi lebih cepat dan up-to-date. Persaingan antara media online pun semakin ketat.

Karena sifatnya yang begitu efisien dan mudah diakses, tidak hanya media online nasional dan internasional saja yang berkembang, melainkan juga media online lokal. Berbagai media online lokal hadir menyuguhkan berbagai macam informasi yang menarik bagi masyarakat lokal karena faktor kedekatan. Sekaligus menjadi sumber informasi atau referensi bagi masyarakat luar yang tertarik. Untuk itu secara tidak langsung media online lokal juga berperan dalam mempromosikan nilai-nilai positif budaya setempat.

Bogor merupakan salah satu kawasan yang cukup populer di Indonesia. Selain karena posisinya yang dekat dengan Ibu Kota Jakarta, Bogor juga terkenal dengan suasananya yang sejuk dan nyaman yang disebabkan oleh tingginya curah hujan di kota tersebut. Untuk itu tidak heran jika banyak khalayak yang menjadikan Bogor sebagai salah satu tujuan wisata. Apalagi diberitakan oleh Antaranews.com untuk tahun 2015 saja kunjungan wisatawan Bogor telah naik sebesar $10.5 \%$. Hal tersebut juga menjadi faktor pendukung hadirnya berbagai portal media online lokal di Bogor yang berlomba-lomba menyediakan informasi terkini dan akurat mengenai kota Bogor, atau sebaliknya, meningkatnya jumlah wisatawan Bogor tidak lain didukung pula oleh informasi yang dihadirkan berbagai media online tersebut.

Dua media online Bogor yang termasuk rutin menyuguhkan pemberitaan mengenai Bogor saat ini adalah www.heibogor.com dan www.bogorplus.com. Keduanya hadir samasama menyajikan informasi yang terjadi seputar Bogor. Meskipun demikian keduanya ternyata memiliki pandangan yang berbeda dalam penyajian informasinya. HeiBogor memiliki karakter pemberitaan yang mengkolaborasikan unsur berita, info komprehensif pariwisata dan gaya hidup melalui konten penyajian yang akurat, berimbang dan terkini berbasis jurnalistik positif. Sementara BogorPlus menempatkan dirinya sebagai media yang berorientasi kepada keadilan (Media for Justice), yaitu sebagai bentuk perlawanan semesta terhadap ketidakadilan dalam kondisi kenyamanan.

Dari sekian banyak berita mengenai Bogor, penulis memfokuskan penelitian terhadap pemberitaan mengenai rencana Optimalisasi Baranangsiang. Pemberitaan tersebut kini memang menjadi salah satu perhatian masyarakat Bogor. Karena keberadaan terminal tersebut tentunya mempengaruhi warga Bogor maupun warga luar kota Bogor yang menggunakan fasilitas terminal sebagai pusat transportasi dalam melaksanakan aktifitasnya

Sekilas mengenai optimalisasi tersebut, ternyata rencana ini sudah ada sejak tahun 2008, menggunakan istilah revitalisasi, yang dapat diartikan sebagai proses atau usaha untuk menghidupkan kembali sesuatu yang sebelumnya terberdaya menjadi vital atau sangat penting. Melihat kondisi terminal yang memang sudah tidak layak, rencana tersebut pada awalnya tentu saja terlihat seperti solusi yang tepat.

Akan tetapi dalam praktiknya, ternyata rencana tersebut malah menemui berbagai batu sandungan. Salah satunya adalah mengenai desain dari revitalisasi yang dikabarkan melibatkan adanya mall dan hotel yang mendapat penolakan dari berbagai pihak, salah satunya warga terminal yang sehari-hari mengais rejeki disana. Penolakan tersebut didasari asumsi bahwa keberadaan mall dan hotel akan menghilangkan fungsi sesungguhnya dari terminal sebagai pusat gerbang transportasi kota Bogor. Kini setelah adanya pergantian pemerintahan di Kota Bogor, rencana revitalisasi ini pun mengalami pergantian istilah menjadi Optimalisasi yang bertujuan untuk memaksimalkan fungsi terminal.

Meskipun bersifat online, kedua media massa tersebut tentunya memiliki tanggung jawab untuk menjunjung tinggi nilai-nilai jurnalistik agar dapat 
memberikan berita yang layak dan dapat dipertanggungjawabkan. Untuk itu analisis framing digunakan oleh peneliti sebagai metodologi untuk mengetahui latar belakang pemberitaan dan keterkaitan prinsip masing-masing media terhadap pemberitaan yang ditampilkan. Analisis framing digunakan untuk melihat bagaimana media mengkonstruksi sebuah realitas yang terjadi sehingga dapat diketahui bagaimana sebuah peristiwa dipahami dan dibingkai oleh media. Metode framing yang digunakan adalah metode Zhongdang Pan dan Gerald M. Kosicki yang terdiri dari empat struktur besar yaitu sintaksis, skrip, tematik dan retoris. Selain analisis teks berita menggunakan framing model Pan dan Kosicki, peneliti juga melakukan wawancara dengan pihak media online HeiBogor dan BogorPlus.

Adapun tujuan dari penelitian ini adalah untuk mengetahui latar belakang pemberitaan dan keterkaitan prinsip media online HeiBogor dan BogorPlus dengan materi pemberitaan yang disajikan.

\section{MATERI DAN METODE}

Penelitian ini menggunakan metode kualitatif deskriptif dengan pendekatan analisis framing. Dalam hal penelitian kualitatif, Creswell dalam Sugiyono menyatakan bahwa penelitian kualitatif adalah proses eksplorasi dan memahami makna perilaku individu dan kelompok, menggambarkan masalah sosial atau masalah kemanusiaan. Penelitian dilakukan terhadap teks berita dari dua media online lokal Bogor yaitu www.heibogor.com dan www.bogorplus.com dengan menggunakan teori analisis framing Pan dan Kosicki.

Unit analisis dari penelitian ini adalah berita straight news terpilih mengenai Optimalisasi Terminal Baranangsiang pada media online www.heibogor.com dan www.bogorplus.com dari tanggal 3 Februari - 6 Mei 2015. Untuk melengkapi data dalam penelitian ini, penulis melakukan wawancara terhadap informan. Informan disini yaitu pihak redaksi media online www.heibogor.com dan www.bogorplus.com yang dianggap kredibel untuk memberikan informasi yang dibutuhkan peneliti.

Model analisis yang digunakan adalah model Pan dan Kosicki yang merupakan modifikasi dari dimensi operasional analisis wacana Van Dijk. Model ini berasumsi bahwa setiap berita memiliki frame yang berfungsi sebagai pusat dari organisasi ide. Pan dan Kosicki membagi perangkat framingnya ke dalam empat kelompok yaitu Sintaksis, Skrip, Tematik dan Retoris yang dapat digambarkan ke dalam skema berikut ini:

Tabel 1. Perangkat Framing Pan dan Kosicki

\begin{tabular}{|c|c|c|}
\hline Struktur & Perangkat Framing & Unit yang Diamati \\
\hline \begin{tabular}{l}
\multicolumn{2}{l}{ SINTAKSIS } \\
Cara wartawan menyusun \\
fakta
\end{tabular} & 1. Skema Berita & $\begin{array}{l}\text { Headline, lead, latar informasi, } \\
\text { kutipan, sumber, pernyataan, } \\
\text { penutup. }\end{array}$ \\
\hline $\begin{array}{l}\text { SKRIP } \\
\text { Cara wartawan mengisahkan } \\
\text { fakta }\end{array}$ & $\begin{array}{l}\text { 2. Kelengkapan } \\
\text { Berita }\end{array}$ & $5 \mathrm{~W}+1 \mathrm{H}$ \\
\hline $\begin{array}{l}\text { TEMATIK } \\
\text { Cara wartawan menulis fakta }\end{array}$ & $\begin{array}{l}\text { Detail } \\
\text { Koherensi } \\
\text { Bentuk Kalimat } \\
\text { Kata Ganti } \\
\end{array}$ & $\begin{array}{l}\text { Paragraf, proposisi, kalimat, } \\
\text { hubungan antarkalimat. }\end{array}$ \\
\hline $\begin{array}{l}\text { RETORIS } \\
\text { Cara wartawan menekankan } \\
\text { fakta }\end{array}$ & $\begin{array}{l}\text { Leksikon } \\
\text { Grafis } \\
\text { Metafora }\end{array}$ & Kata, idiom, gambar/foto, grafik \\
\hline
\end{tabular}




\section{HASIL DAN PEMBAHASAN}

\section{Profil HeiBogor}

Heibogor.com merupakan portal berita online berbasis lokal. Karakter pemberitaan heibogor.com, dengan mengelaborasikan antara berita, info komperhensif pariwisata, dan gaya hidup, melalui konten penyajian yang akurat, berimbang dan terkini.

Untuk melengkapi khazanah informasi, heibogor.com juga menyajikan kanal video, sebagai penunjang berita dan foto. Untuk event-event tertentu, live streaming akan tersedia di kanal ini. Rubrik Mata Bogor tersedia untuk mengakomodasi citizen journalism, baik berupa foto, maupun video.

Heibogor.com yang mengusung tagline ' $100 \%$ Bogor', merupakan bagian yang tak terpisahkan dari spirit penyajian informasi \& komunikasi seputar Bogor. Karakter penulisan berita secara tajam, singkat, padat, dan berimbang sebagai respons terhadap tuntutan masyarakat yang semakin efisien dalam melengkapi kebutuhan informasi.

Visi menjadi ensiklopedia informasi Bogor, baik dari aspek pariwisata, berita terkini, gaya hidup, dan lain sebagainya, menjadi landasan pemikiran dasar berdirinya heibogor.com. Dasar pemberitaan mengusung spirit jurnalisme positif, mengedepankan asas proporsional, dan objektif. Kehadiran heibogor.com, berupaya memposisikan diri pada model bisnis yang berpijak pada tiga asas, yakni industri yang bersumber dan berlandaskan pada Ilmu \& Pengetahuan (Science \& Knowledge), Kreativitas \& Inovasi (Creativity \& Innovation), serta Informasi \& Komunikasi (Information \& Communication).

\section{Profil BogorPlus}

Bogorplus.com adalah media online alternatif yang mendukung pelestarian lingkungan, khususnya pengurangan penggunaan kertas dalam penyempaian informasi. Bogorplus.com adalah media yang berorientasi kepada keadilan (Media for Justice), sebagai bentuk perlawanan semesta terhadap pembodohan, penyesatan, ketidaktertiban, ketidakadilan, kesewenangwenangan, kekerasan, dan keterlenaan dalam zona/kondisi kenyamanan. Dengan pola pendekatan keterpaduan biopsikososial, antroideosprirtual, rasionalitas, logis dan ilmiah, yang keseluruhannya berdasarkan kepada Religi. Bogorplus berpartisipasi mencerdaskan kehidupan bangsa dengan menyebarkan informasi, memberitakan peristiwa, mengulas permasalahan, secara bertanggungjawab baik dunia maupun akhirat.

Pemberitaan di BogorPlus terbagi ke dalam beberapa kanal, yakni kanal Topik Bogor+ yang berisi berita-berita penting dalam bentuk Depth News, Kanal Bogor Raya yang berisi berita-berita dari Kota dan Kabupaten Bogor, Kanal Nasional yang berisi berita-berita nasional dan kanal Dari Bogor Untuk Indonesia yang berisi soft news dalam bentuk features.

\section{Penyebaran Berita dan Hasil Framing di Media Online HeiBogor dan BogorPlus}

Berikut rekap penyebaran berita di media online HeiBogor dan BogorPlus mengenai Optimalisasi Baranangsiang dari tanggal 3 Februari - 6 Mei 2015.

Tabel 2. penyebaran berita Optimalisasi Baranangsiang di media online HeiBogor.

\begin{tabular}{|l|c|c|}
\hline \multicolumn{1}{|c|}{ Rubrik/Kanal } & Jumlah Artikel & Presentase (\%) \\
\hline News & 33 & $91.67 \%$ \\
\hline Government & 1 & $2.78 \%$ \\
\hline Opini & 1 & $2.78 \%$ \\
\hline Bogor Tempo Doeloe & 1 & $2.78 \%$ \\
\hline Jumlah & 36 & $100 \%$ \\
\hline
\end{tabular}


Tabel 3.penyebaran berita Optimalisasi Baranangsiang di media online

BogorPlus.

\begin{tabular}{|l|c|c|}
\hline Rubrik/Kanal & Jumlah Artikel & Persentase (\%) \\
\hline Bogor Raya & 12 & $85.71 \%$ \\
\hline Topik Bogor + & 2 & $14.29 \%$ \\
\hline Jumlah & 14 & $100 \%$ \\
\hline
\end{tabular}

Berdasarkan dua tabel diatas dapat dilihat perbandingan jumlah berita yang cukup jauh antara media online HeiBogor dan BogorPlus mengenai Optimalisasi Baranangsiang. Dimana HeiBogor memiliki lebih banyak berita dalam rubrik News-nya. Berita mengenai Optimalisasi Baranangsiang masuk ke dalam berita yang secara terus menerus diberitakan oleh HeiBogor, sehingga masuk kategori berita andalan.

Sementara untuk BogorPlus jumlah beritanya memang tidak sebanyak HeiBogor, akan tetapi untuk hal Optimalisasi Baranangsiang ini, BogorPlus memiliki 2 artikel dalam Topik Bogor+. Topik Bogor+ sendiri adalah rubrik khusus di media online BogorPlus berisi permasalahanpermasalahan yang dianggap sangat penting dan membutuhkan perhatian yang besar. Sehingga tidak semua berita bisa menjadi bagian dari Topik Bogor+.Sehingga Optimalisasi Baranangsiang ini juga dapat dikatakan sebagai berita andalan di media online BogorPlus.

Adapun perbedaan jumlah berita yang signifikan antara kedua media online tersebut memang berkaitan dengan kebijakan yang berlaku di masing-masing media yang juga berhubungan dengan pandangan masing-masing.Media online HeiBogor mengacu pada salah satu sifat jurnalisme online yang bersifat Real-Time, dimana pelaporan berita berlangsung hampir bersamaan dengan saat peristiwa berlangsung. Apalagi berdasarkan hasil wawancara, dikatakan bahwa wartawan hanya memiliki waktu deadline sebanyak 1 jam sejak peristiwa berlangsung untuk segera melaporkan berita. Berita kemudian diterima oleh redaktur untuk mengalami proses penyaringan dan pengeditan.

Berbeda halnya dengan media online BogorPlus. Sebagai media yang berprinsip pada keadilan, BogorPlus sangatlah selektif dalam melakukan pemberitaan. Faktor kecepatan dalam pemberitaan tidak seketat HeiBogor. Karena BogorPlus lebih mendahulukan kelengkapan isi yang disertai fakta konkrit atau bukti (evidence). Bahkan media online BogorPlus memiliki tim khusus yang bertugas sebagai data collector/data researcher yang bertugas untuk mencari kelengkapan data tersebut. Untuk itulah jumlah pemberitaan di media online BogorPlus tidak sebanyak HeiBogor.

Dari sekian banyak berita mengenai Optimalisasi Baranangsiang, peneliti hanya akan melakukan framing terhadap 4 berita saja dari masing-masing media online. Berita yang dipilih adalah berita yang memiliki kesamaan tema, yang dapat dibagi menjadi :

1. Aksi unjuk rasa penolakan mall dan hotel di Terminal Baranangsiang

2. Pendapat DPRD terkait Optimalisasi Baranangsiang

3. Pernyataan Pemkot dan Bima Arya

4. Pendapat ahli dalam diskusi publik mengenai Optimalisasi Baranangsiang

Peneliti berharap dengan mengkategorikan tema-tema diatas dapat membantu peneliti dalam proses framing untuk lebih memahami bingkai yang digunakan oleh kedua media online tersebut.

Melalui hasil framing dalam sub bab sebelumnya dapat dilihat bahwa kedua media online memiliki frame yang berbeda terhadap pemberitaan mengenai Optimalisasi Baranangsiang. Karena tentunya media online HeiBogor dan BogorPlus memiliki konsep yang berbeda dikarenakan sudut pandang kedua media yang berbeda.Sudut pandang itu mengacu pada prinsip yang sangat mendasar pada masing-masing media online.

Media online HeiBogor memiliki konsep Jurnalistik Positif dengan menjunjung tinggi prinsip cover both sides. Pada media online HeiBogor, Optimalisasi Baranangsiang masuk ke dalam kategori $\mathrm{Hot}$ 
Topic, yaitu kategori berita yang diberitakan secara terus-menerus (di-running) dan dilihat dari berbagai sisi. Contohnya mengapa ada perubahan istilah dari revitalisasi menjadi optimalisasi, siapa saja yang terlibat, siapa saja yang akan terkena dampaknya dan lain-lain.

Persoalan Baranangsiang bagi

HeiBogor merupakan persoalan yang menyangkut kepentingan banyak pihak. Melihat kondisi, terminal Baranangsiang memang sudah nampak tidak layak, untuk itulah optimalisasi dibutuhkan. Pemerintahan sebelumnya yang memberikan ijin pembangunan ternyata memberikan kuasa pada pengembang soal desain terminal, untuk itu walikota berusaha untuk mendapatkan desain baru yang diharapkan sesuai dan dapat mengakomidasi kepentingan khalayak. Heibogor memperlihatkan dukungannya terhadap upaya walikota untuk mengambil langkah hati-hati dalam persoalan Optimalisasi Baranangsiang ini. Yaitu melakukan Optimalisasi sesuai keinginan masyarakat tanpa memutuskan kontrak dengan pengembang.

Konsep sosiologis yang terdapat di HeiBogor berkaitan dengan proses kognitif melalui pengolahan informasi yang dilakukan media dengan cara pandangannya sendiri dan menonjolkan angle atau sudut pandang yang berbeda mengenai sebuah peristiwa yang diharapkan dapat menarik perhatian pembaca.

Sementara itu dalam konsep sosiologisnya, media online BogorPlus menonjolkan prinsip Media for Justice (Media untuk keadilan) dalam bentuk berita yang apa adanya serta penyertaan faktafakta konkrit atau bukti (Evidence).

Sehingga tidak aneh jika membahas persoalan Optimalisasi Baranangsiang, BogorPlus lebih banyak mengupas dari perspektif hukum. Untuk jumlah berita pun BogorPlus terlihat lebih sedikit karena selektifitas yang tinggi dalam hal pemberitaan. Hanya berita-berita yang dianggap penting untuk diketahui masyarakatlah yang akan dimuat oleh BogorPlus. Hal itu didasari tujuan untuk sekaligus melakukan edukasi kepada pembaca atau masyarakat.
Optimalisasi Baranangsiang, yang menjadi perhatian BogorPlus adalah adanya kemungkinan pelanggaran UU Tata Ruang, karena diikuti dengan pembangunan mall dan hotel. Apalagi dalam kontrak antara Pemkot dan pengembang, ternyata porsi terminal sangatlah kecil dibandingkan dengan mall dan hotel yang akan dibangun.

Penggunaan bahasa pun kedua media online ini cukup berbeda. Media online HeiBogor mengutamakan keringkasan dalam setiap beritanya. Sehingga terkadang berita terlihat minimalis dan straight to the point. Media online BogorPlus pun memiliki karakter straight to the point akan tetapi tidak begitu membatasi isi berita jika terdapat bukti-bukti atau fakta yang dapat menambahkan kelengkapan berita. Bahkan dalam proses pencarian berita, BogorPlus memiliki tim khusus yang bertindak sebagai data collector/data researcher yang tugasnya adalah mencari kelengkapan data dan bukti yang akan dihadirkan dalam berita yang disajikan.

\section{KESIMPULAN DAN SARAN}

\section{Kesimpulan}

Berdasarkan hasil penelitian terhadap pemberitaan media online HeiBogor dan BogorPlus mengenai Optimalisasi Baranangsiang dan juga wawancara yang peneliti lakukan terhadap pihak redaktur kedua media online tersebut, maka dapat disimpulkan bahwa memang terdapat keterkaitan antara prinsip media online terhadap pemberitaan yang disajikan.

Media online HeiBogor mengusung jurnalistik positif, menghasilkan beritaberita yang ringkas dengan bahasa yang mudah dimengerti oleh hampir semua kalangan masyarakat. Jumlah berita yang dihasilkan pun lebih banyak dan disajikan dengan cepat karena konsep real-time yang dianut, dimana pelaporan berita hampir bersamaan dengan saat peristiwa berlangsung. Sehingga untuk Optimalisasi Baranangsiang, bingkai yang digunakan adalah bahwa optimalisasi tersebut melibatkan kepentingan banyak pihak 
sehingga harus dilihat dari berbagai sisi untuk mendapatkan solusi terbaik.

Sementara untuk media online BogorPlus, mengusung prinsip Media for Justice (Media untuk keadilan) menjadikannya sebagai media yang kerap mengangkat permasalahan yang ada di masyarakat melalui perspektif hukum. Sehingga bingkai yang digunakan dalam perihal Optimalisasi Baranangsiang adalah mengenai rencana pembangunan hotel dan mall di Terminal Baranangsiang sebagai suatu tindakan pelanggaran hukum karena tidak sesuai dengan UU Tata Ruang yang berlaku. Jumlah berita pun lebih sedikit karena selektifitas tinggi dari media online BogorPlus. Berita pada media online BogorPlus adalah output yang diupayakan untuk mencerdaskan masyarakat Bogor. Tidak ada pembatasan panjang berita selama bukti yang disertakan memang relevan.

\section{Implikasi Penelitian}

Dari penelitian terhadap kedua media online tersebut, ada beberapa implikasi yang peneliti harapkan bisa menjadi masukan bagi redaksi HeiBogor maupun BogorPlus khususnya dalam hal pemberitaan. Meskipun implikasi ini tidak sempurna namun diharapkan dapat menjadi catatan bagi kedua redaksi dalam pengembangan berita serta dalam pengembangan penelitian yang serupa.

Adapun implikasi yang dimaksud sebagai berikut :

1. Peneliti harus lebih proaktif lagi dalam menghubungi informan untuk penjadwalan wawancara. Apalagi jika informan memiliki tingkat kesibukan yang tinggi. Proses wawancara memang paling baik dengan metode tatap muka untuk dapat menggali informasi lebih dalam. Apabila tidak memungkinkan, penggunaan sarana lain seperti telepon atau pun email dapat menjadi alternatif.

2. Untuk dapat memiliki bukti atau fakta yang lebih mumpuni, sebaiknya HeiBogor juga memiliki team data collector atau data research seperti yang dimiliki BogorPlus.

3. Untuk menggali lebih dalam mengenai keinginan masyarakat terkait optimalisasi Baranangsiang, ada baiknya pihak media online selain memberitakan, juga melakukan survey atau jajak pendapat yang mewakili setidaknya masyarakat Bogor yang berada di sekitar Baranangsiang.

4. Untuk penelitian selanjutnya dalam membandingkan media online dalam studi framing, peneliti selanjutnya dapat mencoba menggunakan teori framing lain seperti misalnya teori Robert T. Entman untuk melihat bagaimana posisi atau kecenderungan sebuah media dalam memahami dan mengkonstruksi sebuah isu.

\section{DAFTAR PUSTAKA}

Ardianto, Elvinaro dkk.2007.Komunikasi Massa Suatu Pengantar. Bandung: Simbiosa Rekatama Media.

Eriyanto. 2012. Analisis Framing (Konstruksi, Ideologi dan Politik Media).Yogyakarta : Penerbit KliS.

Bungin, M.H. Burhan. 2007. Penelitian Kualitatif. Jakarta : Penerbit Kencana Prenada Media Group.

Sobur, Alex. 2012. Analisis Text Media.Bandung : PT Remaja Rosdakarya.

Sugiyono. 2013. Cara Mudah Menyusun Skripsi, Thesis dan Disertasi. Bandung : Penerbit Alfabeta. 